\title{
SOME GUESSES ABOUT YANKEE DOODLE
}

\author{
By FRANK KIDSON
}

7 o the musical antiquary there lies in the tune Yankes Doodlo the same mystery and fascination that lurks in the smile of the Mona Lisa of the Louvre. Small wonder then that for generations so many writers have spilled ink and made wild guesses in the hope of finding out the truth regarding its origin, a task as futile assuredly as solving the problem who wrote God Save the King. To the Library of Congress, some years ago, was officially assigned the labour of picking up the ends of all the tangled skeins that have got twisted round the subject, to unknot these and lay bare the innermost heart of the question. In the "Report on The Star Spangled Banner, Hail Columbia, America, and Yankee Doodle" issued from the Library of Congress in 1909, much was done to knock on the head wild statements and absurd theories that had been made and broached since the history of the tune had become a matter of interest. Like the rest of us, the author left the origin of the tune still a mystery though he succeeded in clearing away a great deal of the rubbish which encumbered and blocked the search. It is not my intention to recapitulate any of the Report's arguments or discoveries, or to encroach on any of its ground. The book is so inexpensive and so full of interest for any student of national song that it is imperative that it should be obtained and placed in the library of every musician; it is a monument of patient and learned research. My own task is to add a few guesses and to leave the reader to draw his own conclusions as to the value of the propositions I put forth.

The mystery of the tune carries with it the mystery of the words "Yankee" and "Doodle," Wild flings into philology have been made into languages which range in currency from the territory of the Cherokee Indians to the Persian Gulf. Still, each derivation leaves us cold and doubtful. We have been told numerous stories to account for its existence as an American national air, none of which we really have faith in, but which we idly accept as the easiest and least troublesome way of accounting for the circumstance. 
You will find them all in the Report of 1909 , and I feel sure will mentally shed the tributary tear of pity for the author who has had to painfully accept them temporally until he has with pain and travail knocked them on the head until they were apparently dead; for many of these wild statements will rise again and form themes for future historians to quarrel over. The present article will possibly add to the labours of these musical antiquaries and may even rouse some of the present day ones to a contention of the theories I now broach.

Yankee Doodle is among the queer tunes. It has never settled its own time-rhythm. We can take it in 6-8, in 2-4, and in common time with equal authority, for it is to be found printed with each of these time signatures, and to the ordinary person one is as good as another. It has also considerable variation in note and few if any old copies are identical with each other. I think I may claim to have been the first to put on record the fact that the earliest printed copy of the tune, under the title $Y$ anky Doodle, appears in the first volume of Aird's "Selection of Scotch, English, Irish, and Foreign Airs, for the fife, violin or German Flute." In my "Old English Country Dances," 1890, I reproduced the tune from Aird and fixed the date of his publication as "about 1775 or 1776." Afterwards I accepted the late Mr. John Glen's date "1782," but on going very carefully into the matter I find full evidence that $I$ was correct in my original estimate of date.

Aird's "Selection" is one of those rare little collections which are the joy of collectors. It is in six small oblong volumes, each measuring only six and a half inches, by four and a quarter. Originally commenced as a single volume by James Aird, an obscure Glasgow music seller, it sold so well that a second volume was published in 1782 , a third in 1788 , a fourth in 1794 , a fifth in 1797 and a sixth, early in the 19th century. Aird having died in 1794 the three last books were issued by his successor, and the whole series reissued by this successor, and again by George Goulding, a London publisher.

Aird's little book is composed of tunes suitable for the drum and fife band of a regiment, and includes many regimental marches. The Military drum which is the chief feature of the engraved title page is inscribed "Royal Glasgow Volunteers," and upon that body and similar companies Aird probably depended for a sale.

It is a matter for speculation from what source Aird got his Yanky Doodle. It is evident that he had an American 
correspondent, for he includes a sprinkling of tunes from across the Atlantic such as several "Virginian" airs, a "Negro Jig" and so forth. Yanky Doodle, as given by Aird, has a number of variations.

The fact remains that up to the present no earlier copy of Yankee Doodle has been found in print prior to Aird's publication which, as I have already stated, there is evidence to show was published about 1775 or 1776 ; certainly before 1778 . Nor can we be certain that any manuscript copy exists of even a few years earlier. I have before said that every old copy of the tune varies considerably and that is a strong proof that it has existed for a period entirely by tradition, and passed from lip to lip, or from instrument to instrument. It has been noted down in manuscript books of airs to be played on the violin, or more frequently the German flute, the instrument which every young gentleman of culture in England and America tootled on from the middle of the 18th century to our grandfather's time. That Yankee Doodle was chiefly played on the flute or fife in its early days is, I think, very likely; it certainly lends itself to these two instruments.

I have not, myself, come across any early copy arranged for the harpsichord or pianoforte save three. The first occurs in the published score of Dr. Arnold's opera "Two to One," produced in 1784, the second in Charles Dibdin's "Musical Tour", printed at Sheffield in 1788, and the third is reproduced in Mr. Sonneck's Report from a music sheet published by Thomas Skillern of London sometime after 1777. In all three instances the songs are adapted to the tune and are not the original words (if any such existed) to the air.

Arnold's song Adzooks old Crusty why so rusty, forms part of his opera. Dibdin's song The Return of Ulysses to Ithaca is a burlesque version of that hero's adventures, and the third is entitled Yankee Doodle or, as now christened by the Saints of New England, The Lexington March. This is a scurrilous song in ridicule of the Americans. The words "now christened The Lexington March" sufficiently show that the tune was in existence before the words, also that it was re-named after the battle of Lexington. Anyhow I am anxious to show that the tune was a tune pure and simple, and while many sets of nonsense verses have been put to the air they were not united with it until it had become a popular one, as a tune solely.

Many musical people in those days were content to play simple airs on flute, or violin, without other accompaniment. The tune and the performer stood on their own merits and were not bolstered up by harmony or the backing of a second performer. 
The man in his solitude unscrewed his flute and tootled into it to his own satisfaction, if not to that of his neighbours.

I assert, (I feel sure, correctly,) that Yankee Doodle has been evolved on the flute or fife, most likely the latter, by an amateur musician. I should fix the nationality of this person, unknown to fame, as American. My reason for these conclusions will appear later on. I do not see any great antiquity in the melody; I should very much doubt whether it went so far back as 1740 , inclining to a date ten or twenty yearg later.

Another point in my argument is the fact that while fragments of nonsense verse have been adapted to the tune these have had no stability and have varied as fancy or political situations have dictated. It is, I think, quite obvious that the air has not been composed for words, but has been evolved as a sprightly dance melody. Its connection with the dance is indicated by one of the early choruses used to the tune:-

Yankey Doodle keep it up,

Yantej doodle dandy;

Mind the muric and the step.

And with the girls be handy.

We may now consider the question of the name "Yankee Doodle," for the title has never been satisfactorily explained. Much diving into records has elicited the fact that the earliest known use of the word "Yankee" goes back to 1725 at which date a negro man named "Yankee" is to be sold. (See Notes and Queries vol. 10, 1878). Further we find that the word "Yankey" is a nickname in use in America a little later than that time, and we know that in due course natives of the eastern states of America became nominated, vulgarly, "Yankees."

It is a futile task to attempt to trace the derivation of "Yankee" but I wish to point out that the words "Yanko" and "Yarico" have been used by English writers as typical proper names for Indians on the further side of the Atlantic, just in the same way that they might use "Mustapha" for a Turk, or "Paddy" for an Irishman. For example in the 11th number of "The Spectator" dated March 13, 1710-11 there is the tale of Inkle and Yarico told-or retold. Thomas Inkle is wrecked on the mainland of America and befriended by Yarico an Indian girl. On getting to the West Indies by an English ship he basely sells her into slavery.

Charles Dibdin in writing his opera "The Islanders," produced November 1780, -a work evidently inspired by Captain 
Cook's voyages among the South Sea Islands-named the principal male savage "Yanko." We have seen that the negro man of 1725 bore the name "Yankee" and that the same name was a nickname indicating an American a few years later, therefore I venture to conclude that "Yanko" or "Yankee" has been used in friendly raillery for the Americans, indicating them as Indians, just as we might speak of the Irish as "Paddies," the Scotch as "Sandies," and so forth. If any one chooses to push the search further I would suggest that they note how often the name "Yanko" is used as a proper name in early stories dealing with American or savage life.

The word "Doodle" is equally obscure. As explanation, I think it will be found within everybody's experience that nurses in singing to children, also other people, vocalise a melody, where the proper words are not used, or are not known, by singing the air to such words as "Doodle, doodle" with a final "doodle, doodle do."

In fact in more than one country district in England this way of singing a tune is called "deedling," or "doodling."

Dr. Wright's Dialect Dictionary gives a quotation which confirms this. A correspondent writes him:

A friend, a fiddler told me he had learnt a certain tune by an old man "doodling it" by singing or humming it bit by bit until he learnt the whole.

Also, it must be noted that the 18th century flute tutors, and later ones, instruct the learner in "double tongueing" to pronounce the word "tootle" as he blows into the flute. The words "doodle" and "tootle" are sufficiently alike to believe that the one may be used for the other indifferently.

Accepting the above as reasonable propositions it is conceivable that the title Yankes Doodle may have come from "The Yankee Tootle," or "The Yankee Doodle," meaning the American air that has no words, and perhaps not a known title, which is "tootled" on the flute or "doodled" by the voice.

In making this suggestion I emphasise the fact that no words appear to have been coexistent with the birth of the tune, and that it is eminently a flute or a fife tune.

I put forth all these suggestions with humility but I think they are at least as reasonable as most others that have been made in regard to the intricate problem.

I append Aird's original version and several early copies from manuscript books of airs in my own possession. Also a 
Yankee Doodle

From a menuecript book of alre writton about 1890 - 8

bolonglas to F. Yideon
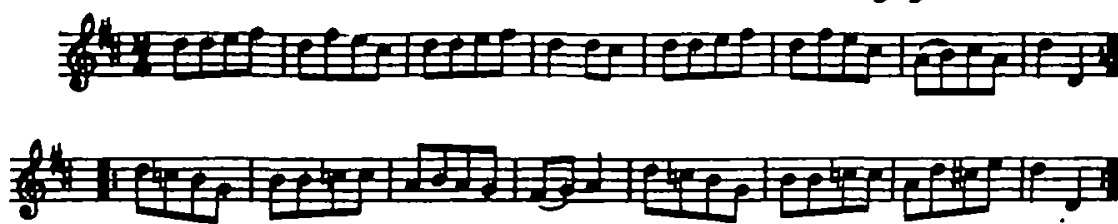

Yankee Doodle

From a menuectipt book of alre circe 1802

bolongting to F. Bideon

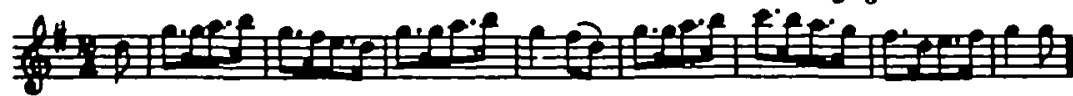

ใ.

Yankee Doodle

Prom a flute tutor, tlthe miesing circa 1828

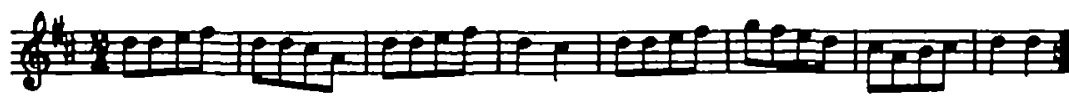

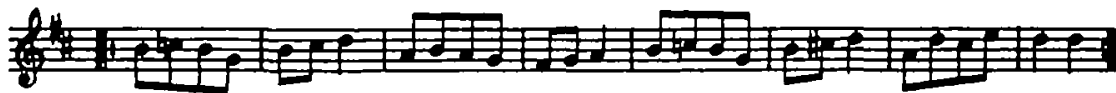

London now is out of Town

From "Mmatral Laye" ctrca 1820
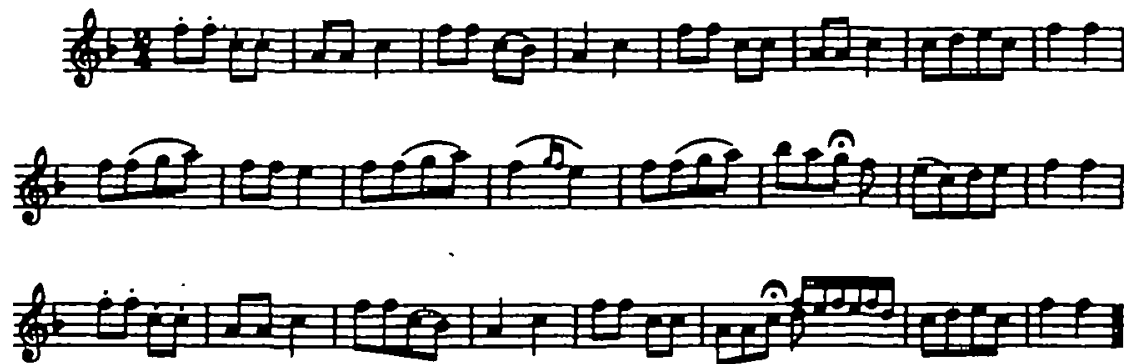
Yanky Doodle

Fram Aird' "Selootion". Vol. I circe $1778 \cdot 8$
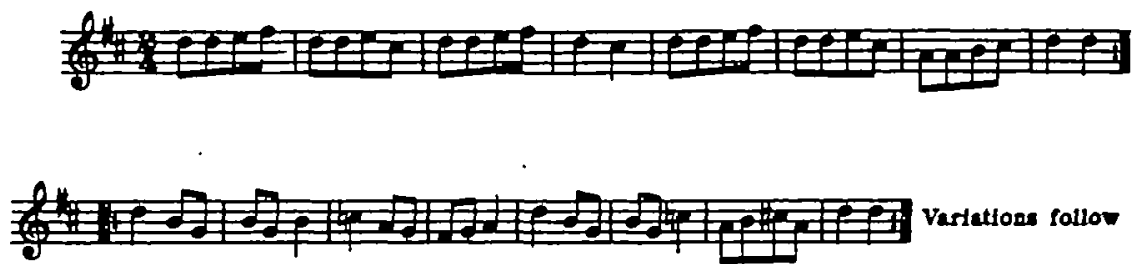

Yankie Doodle

From a manuscript book of alrs in possestion of Frent Rideon. On the first cover is written "Goorge (r) Catt 1700." On ond corer is writton "John Carter given wo by Stopten Catt when gotag away May 100h 1792." Those are about seventy airs, all wrttion in one band, evidently that of Oeorge Catt. Oblong 8vo
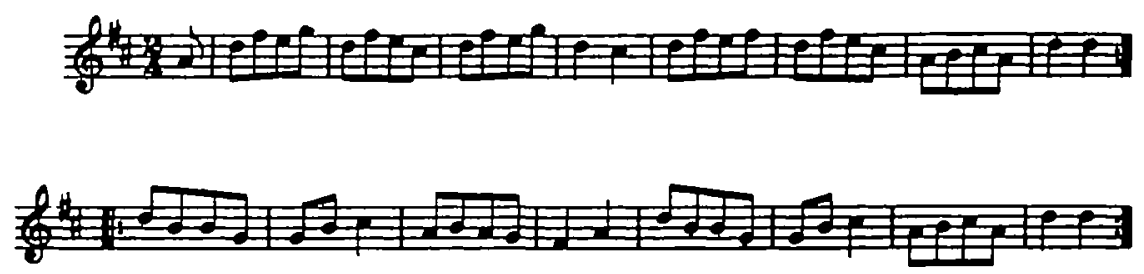

The Lexington March

From menuscript book of als ctra $1708-1800$ belositing to F. Fideon
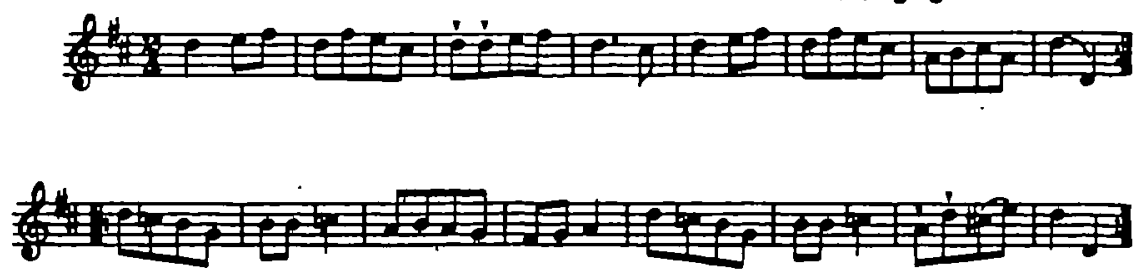
curious use of the tune of a song by Theodore Hook, London now is out of Town published in a work called "Minstrel Lays," a collection of popular airs for the flute published by James Power of London about 1820. The name "Ware" is attached to the tune: evidently William Henry Ware, a musician attached to Covent Garden and producer of pantomimes, etc., He probably arranged and harmonised Hook's song for theatrical or concert performance.

I have estimated the dates of my manuscript books as closely and as carefully as passible. 